\title{
Export and Import Performance of Agriculture in India
}

\author{
J.Sheeba, R.Reena
}

\begin{abstract}
Agriculture plays a significant role in Indian economy. Indian Agricultural export and import have undergone foremost change in this modern era. The study focus the analysis related to the export and import performance of Indian agricultural sector. This study covers the export and an Import category includes cereals, fresh fruits and vegetables, animal products, floriculture, processed food and organic product. Non Basmati Rice, Basmati rice, Fresh Vegetables, Buffalo Meat and Fresh fruits are the top five Agricultural exported products from India. Pulses, wheat, other fresh fruits, Alcoholic Beverages and Other Cereals are the most imported products. The study is based on secondary data which is drawn on quantitative and qualitative data, document, records and information available in Agricultural and processed Food Products Export Development Authority (APEDA). The paper highlights the fact performance of India, agricultural export and import from 2008 - 09 to 2017 18. The trade balance between export and import of agricultural in India is positive. The percentage share of total export in past few decades is fluctuating. The performance of import decreases in 2014 - 2018. The agricultural growth rate in export is $10.53 \%$ (2017 - 18) and the agriculture import growth rate is $\mathbf{- 3 6 . 1 3 \%}$ $(2017-18)$.
\end{abstract}

Index Terms- Agricultural, Export and Import, Trade Balance and Growth.

\section{INTRODUCTION}

Indian Agricultural product has occupied a unique place in the world agriculture product. India is the world largest producer of various ranges of commodities due to its favorable agro-climatic conditions and rich natural resource base. The contribution of agricultural export and economic growth has forward and backward relationship. India, the central place of exporting agricultural commodity like Basmati Rice, Non Basmati Rice, Cereal Preparations, Fresh Onions, Pulses, Maize, and Other Fresh Fruits. This study assessed the contribution and impact of growth of agricultural exports and import in India. Present study explores the growth performance of Indian Agricultural Export and Import from 2008 - 09 to 2017 - 2018. The data Source collected from Agricultural and processed Food Products Export Development Authority (APEDA) established by the government of India in 1985.

\section{OBJECTIVE OF THE STUDY}

1. To analysis the agricultural export and import in India.

2. To determine the Growth level in Agricultural export and import.

Revised Manuscript Received on September 14, 2019

J.Sheeba, Ph.D Research Scholar, Sri Krishna College of Arts and Science, Coimbatore, Tamilnadu, India.(E-mail: sheebaj02@gmail.com)

Dr. R.Reena, Professor \& Head, Sri Krishna College of Arts and Science, Coimbatore, Tamilnadu, India.(E-mail: reena_louis99@yahoo.com)

\section{METHODOLOGY}

The study is based on Secondary data and the required data is collected from Agricultural and Processed Food Products Export Development Authority (APEDA). The analysis is carried from the period of 2008 - 09 to 2017 18. The tools adopted for study are Common Size method, Agricultural Export and Import Trade Balance and Growth of Export and Import in India.

\section{KEY MEASURES TAKEN FOR PROMOTION OF EXPORTS}

A new Foreign Trade Policy (FTP) 2015-20 was launched on 1st April 2015. The policy rationalized the earlier export promotion schemes and introduced two new schemes Merchandise Exports from India Scheme (MEIS) for improving export of goods and Services Exports from India Scheme (SEIS) for increasing exports of services. Duty credit scrip's issued under these schemes were made fully transferable.

The Mid-term Review of the FTP 2015-20 was undertaken on 5th December, 2017. Incentive rates for labour intensive / MSME sectors were increased by $2 \%$ with a financial implication of Rs 8,450 crore per year.

Interest Equalization Scheme on pre and post shipment rupee export credit was introduced from 1.4.2015 which providing interest equalization at $3 \%$ for labour intensive MSME sectors. The rate was enlarged to 5\% for MSME sectors with effect from 2.11.2018 and merchant exporters were covered under the scheme with effect from 2.1.2019.

A new scheme called "Trade Infrastructure for Export Scheme (TIES)" was launched with effect from $1^{\text {st }}$ April 2017 to address the export infrastructure gaps in the country.

A comprehensive "Agriculture Export Policy" was launched on 6th December, 2018 with an aim to double farmers' income by 2022 and in order to an impetus to agricultural exports. 


\section{ANALYSIS AND INTERPRETATION \& RESULTS}

Table -5.1

Agricultural Export and Import Trade Balance

\begin{tabular}{|l|l|l|l|}
\hline Year & Export & Import & $\begin{array}{l}\text { Trade } \\
\text { balance }\end{array}$ \\
\hline $2008-09$ & 35473.93 & 38485.38 & -3011 \\
\hline $2009-10$ & 35349.89 & 53888.35 & -18538 \\
\hline $2010-11$ & 42437.18 & 41762.70 & 674 \\
\hline $2011-12$ & 83484.33 & 31534.99 & 51949 \\
\hline $2012-13$ & 118250.96 & 23977.41 & 94274 \\
\hline $2013-14$ & 136921.21 & 22676.13 & 114245 \\
\hline $2014-15$ & 131343.00 & 17976.70 & 113366 \\
\hline $2015-16$ & 107431.89 & 14559.73 & 92872 \\
\hline $2016-17$ & 108426.73 & 15924.46 & 92502 \\
\hline $2017-18$ & 119846.65 & 10170.61 & 109676 \\
\hline
\end{tabular}

The total export and import of India during the period of 2008 - 2018 have exceeded the volume of exports, which resulted in a positive trade balance. From this Table 5.1 it is inferred in a negative trade balance -3011 in $2008-09$, and -18538 in $2009-10$. Although there has been some increase in the last three years Rs.674 crores in 2010 -11, Rs.51949 crores in 2011 - 12 and Rs. 94274 crores in 2012 - 13. In 2013 to 2015 the trade level increased substantially to Rs. 114245 Crore in 2013 - 14 and Rs. 113366 crores in 2014 - 15 but it has come down Rs.92872 crores in 2015 16 and Rs.92502 crores in 2016 - 17 and finally to Rs. 109676 crores in 2017 to 2018 is increased while comparing with past two years. It shows the trade balance is positive in agricultural export and import in India.

TABLE - 5.2

Agricultural Growth Rate in Export

\begin{tabular}{|l|l|l|}
\hline YEAR & EXPORT & GROWTH \% \\
\hline $2008-09$ & 35474 & \\
\hline $2009-10$ & 35350 & -0.35 \\
\hline $2010-11$ & 42437 & 20.05 \\
\hline $2011-12$ & 83484 & 96.72 \\
\hline $2012-13$ & 118251 & 41.64 \\
\hline $2013-14$ & 136921 & 15.79 \\
\hline $2014-15$ & 131343 & -4.07 \\
\hline $2015-16$ & 107432 & -18.21 \\
\hline $2016-17$ & 108427 & 0.93 \\
\hline $2017-18$ & 119847 & 10.53 \\
\hline
\end{tabular}

The above table 5.2 export of India has faced a very challenging period in recent year, on account of developments arising from the global financial crisis of $2008-2009$, there is negative growth rate. $20.05 \%$ increase in the year $2009-10$. Then export has been raised $96.72 \%$ in the year 2011-12. However, agricultural growth started to fall $41.64 \%$ in the year $2012-13,15.79 \%$ in the year 2013 -14 . The export was fallen about $-4.07 \%$ in the year $2014-$ 15 and -18.21 in the year 2015-16. The share of agricultural export increases $0.93 \%$ in $2016-17$ and $10.53 \%$ in the year 2017-18. So this leads to the fluctuation in agricultural.

Table - 5.3

Agricultural Growth Rate in Import

\begin{tabular}{|l|l|l|}
\hline YEAR & IMPORT & GROWTH \% \\
\hline $2008-09$ & 38485 & \\
\hline $2009-10$ & 53888 & 40.02 \\
\hline $2010-11$ & 41763 & -22.50 \\
\hline $2011-12$ & 31535 & -24.49 \\
\hline $2012-13$ & 23977 & -23.97 \\
\hline $2013-14$ & 22676 & -5.43 \\
\hline $2014-15$ & 17977 & -20.72 \\
\hline $2015-16$ & 14560 & -19.01 \\
\hline $2016-17$ & 15924 & 9.37 \\
\hline $2017-18$ & 10171 & -36.13 \\
\hline
\end{tabular}

Table 5.3 present Indian imports by agricultural commodity with their growth rate respectively during 2008 - 09 to 2017 - 18. Import in 2009 - 10 stood at Rs. 5388 crores with a growth of $40.02 \%$. However, this growth in Indian import has come down, a negative annual growth rate during last six years from $22.50 \%$ in the year 2010-11, $24.49 \%$ in the year $2011-12,23.97 \%$ in the year $2012-13$, $5.43 \%$ in the year $2013-14,20.72 \%$ in the year $2014-15$ and $19.01 \%$ in the year $2015-16$. There were substantial positive growths in Indian import during 2016 - 17, 9.37\%. Significantly, import has performed highest negative growth rate of $36.13 \%$ in $2017-18$.

Figure - 5.1

Indian Agricultural Export performance During 2008 - 2018

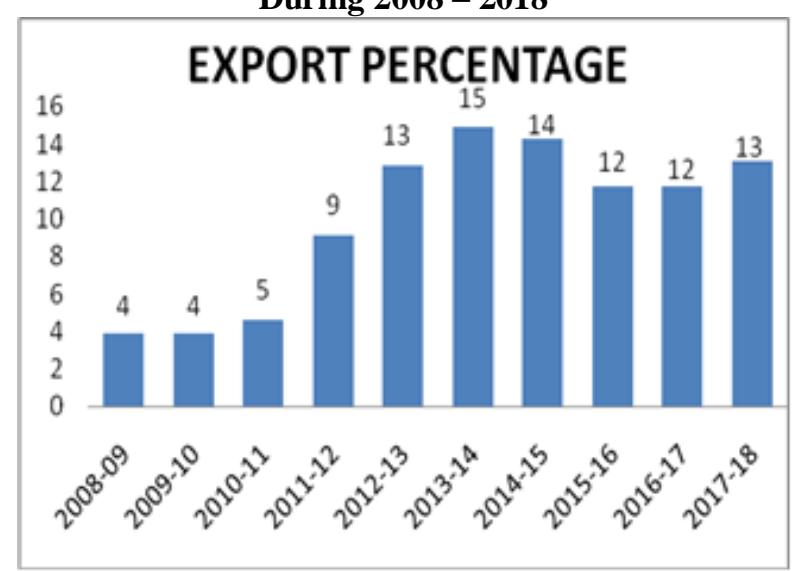

The above Figure 5.1, it can be inferred the agricultural total export has declined to $4 \%$ in the year $2008-09$ and 2009- 2010, but later export of agricultural grew at an average of $5 \%$ in $2010-11,9 \%$ in $2011-12$, there was an increasing trend over an a periods of $13 \%$ in 2012-13 and the growth size increased $15 \%$ in the 2013-14. After that it's started to reduce to $14 \%$ to $12 \%$ in the year 2014 to 2017 . Export of agricultural recouped with growth of $13 \%$ in the year 2017 to 2018 . The growth of agricultural export

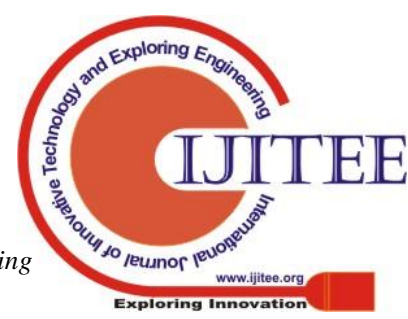


is fluctuating in recent years and also expanded. It was observed during the study period export increased in size.

Figures $\mathbf{- 5 . 2}$

Indian Agricultural Import performance during 2008 - 2018

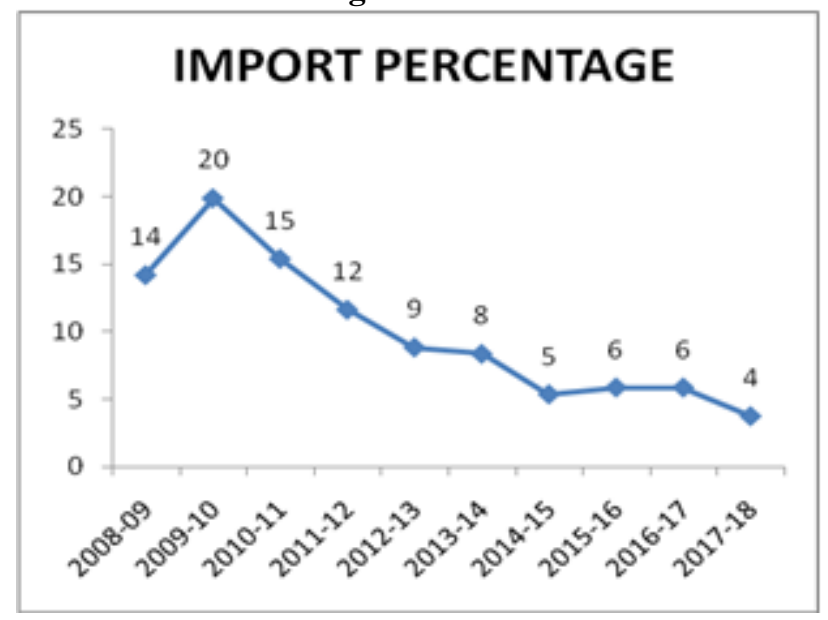

The volume of import of these grains increased by $14 \%$ to $20 \%$ in the year $2009-2010$. The goods imported fluctuating trend from $15 \%$ in the year $2010-11,12 \%$ in the year $2011-12,9 \%$ in the year $2012-13,8 \%$ in the year $2013-14$ and $5 \%$ in the year $2014-15$. The importing of goods increased $6 \%$ in the year 2015 to 2017 . The farmers who produced them are the center of the current crisis due to the worst hit by the fall in the prices caused by the import. The import slightly fallen in the year 2017 - 18 as depicted in fig.5.2.

\section{CONCLUSION}

The Indian agriculture export had been occupying the place of pride in the export. Even though, there is an increase in the quantum of agricultural exports, there is consistent decline in the agricultural growth in total exports from 20.05 percentages to 10.53 percentages during the study period. The agricultural growth rate import in India has been fluctuating and it shows in table 5.3. The increasing trend in the value of export from 2010 to 2018, it was a successful in terms of agricultural export increase value and quantity. Indian agricultural export performance during 2008 to 2018 has been increase in the agricultural export since the onset of globalization and liberalization. The findings of the studies show that the Indian agriculture exports have been increased while compares to import. The Indian government needs to take some effective steps to raise its agricultural export with helping the exporters.

\section{REFERENCES}

1 Dr.RajKumar, Varsha Dadhich, "Growth and Performance of India's Agriculture Export," International Journal of $360^{\circ}$ Management Review, vol. 01, Issue. 01 pp. 1-13, April 2013.

2 Tawjeed Nabi, Dr. Jasdeep Kaur Dhami, "Analysis of India's Agriculture Export Performance in Pre and Post WTO Regime," International Journal of Enhance Research in Management \& Computer Applications, vol. 2, Issue 4 pp. 1-5, April 2013.
3 Neha Sinha, "Agriculture and Allied Commodities anchor India's Export," National Commodity \& Derivatives Exchange Ltd, vol. 01, February 2013.

4 Dr.Sunny Thomas, Waheeda Sheikh, "Growth and Composition of Indian Agriculture Exports during reform era," National Monthly Refereed Journal of Reasearch in Commerce \& Management, vol. 01, Issue 6, February 2010.

5 APEDA, "Indian Agri Exports: Study on Difficulties faced by the exporters in the supply chain of agriculture products", September 2016. 